\title{
Rancang Bangun Mesin Pemberi Pupuk Cair Otomatis Hemat Daya Berbasis Iot untuk Budidaya Tanaman Organik
}

\author{
Diana Shofa*, Deandra Tavania Dewi, Ikhwan Muhammad Faris \\ Ihda Fuad Baharudin, Herlina Mitasari, Aryo Satito \\ Teknik Mesin, Politeknik Negeri Semarang, Indonesia \\ J1. Prof. Soedarto Tembalang Kota Semarang 50275 \\ *E-mail: dianashofa09@gmail.com \\ Diterima: 21-11-2020; Direvisi: 04-02-2021; Dipublikasi: 27-04-2021
}

\begin{abstract}
Abstrak
Pemupukan menjadi proses penting dalam budidaya tanaman organik. Proses pemupukan yang tidak merata, tidak terjadwal, dan kurang terukur berpeluang menurunkan hasil panen. Rancang bangun alat pemberi pupuk cair otomatis untuk budidaya tanaman organik diperlukan agar proses pemupukan menjadi lebih efektif dan efisien, sehingga mampu memperbesar peluang peningkatan hasil panen. Penelitian ini dilakukan untuk membuat rancang bangun mesin pemberi pupuk cair otomatis hemat daya berbasis IoT untuk budidaya tanaman organik. Dalam penelitian ini dilakukan perancangan sistem alat yang dapat mengintegrasikan fungsi Arduino, sistem IoT dan panel surya untuk lebih hemat daya. Kebutuhan pembuatan alat meliputi dosis pupuk cair, jumlah water sprinkler, kebutuhan pipa, alat ukur kelembaban tanah dan kapasitas solar cell. Hasil penelitian ini menghasilkan keluaran debit air $600 \mathrm{~L} /$ hektar dengan jangkauan keluaran pupuk cair yang disemprotkan $50 \mathrm{~m}^{2}$ tiap water springkler membentuk lingkaran. Waktu penyemprotan yang lebih singkat, jangkauan yang lebih luas, kemudahan mengontrol alat, dan hemat daya menjadikan alat ini menarik untuk diterapkan dalam budidaya tanaman organik agar mampu menghasilkan panen yang lebih baik. Hasil ini dapat digunakan sebagai referensi dalam merancang mesin pemberi pupuk cair otomatis hemat daya berbasis IoT untuk budidaya tanaman organik.
\end{abstract}

Kata kunci: otomatis; pemupukan; tanaman organik

\begin{abstract}
Fertilization is an important process in cultivating organic plants. The fertilization process is uneven, unscheduled, and less measurable which reduces harvest. The design of an automatic liquid fertilizer application for cultivating organic plants is needed so that the fertilization process becomes more effective and efficient to increase the harvest. This research was conducted to design a power-efficient, automatic liquid fertilizer application based on IoT for the cultivation of organic plants. In this research, the design of a device system that can be integrated with the Arduino function, the IoT system and solar panels to save more power. Equipment manufacturing needs include the dosage of liquid fertilizer, the number of water sprinklers, pipe requirements, soil moisture measuring equipment and solar cell capacity. The results of this study produce an air discharge output of $600 \mathrm{~L} /$ hectare with an output range of $50 \mathrm{~m} 2$ of liquid fertilizer sprayed each forming a circle. The shorter spraying time, wider range, tool control, and power saving make this tool attractive to be applied in organic crop cultivation in order to produce better harvests. These results can be used as a reference in built to IoT-based power automatic liquid fertilizers for cultivating organic plants.
\end{abstract}

Keywords: automatic; fertilization; organic plants

\section{Pendahuluan}

Salah satu proses budidaya tanaman organik yang penting diperhatikan adalah proses pemupukan. Pemupukan biasanya dilakukan dua kali sehari yaitu pagi sebelum matahari terbit dan jam 4 - 6 sore menggunakan pupuk cair. Teknologi pemupukan yang sesuai menjadi salah satu cara dalam meningkatkan produktifitas hasil panen [1]. Saat ini, masih banyak proses pemupukan tanaman organik menggunakan cara manual. Proses pemberian pupuk cair yang masih dilakukan secara konvensional dengan alat penyemprot tanaman sederhana menyebabkan dosis pemberian pupuk yang tidak terukur, penyemprotan tidak merata serta waktu pemupukan yang tidak terjadwal dan terkontrol. Hal ini 
berpeluang menurunkan hasil panen. Menurut Marpaung dkk. [2] pemupukan menjadi salah satu usaha penting untuk meningkatkan produksi, bahkan sampai sekarang dianggap sebagai faktor yang dominan dalam produksi pertanian.

Dikalangan petani tanaman organik seringkali telat dalam hal pemberian pupuk yang seharusnya dilakukan sebelum matahari terbit justru dilakukan pada jam 8 - 9 pagi. Hal ini mengakibatkan pupuk cair yang mengenai daun banyak menguap ke udara sebelum terserap sempurna oleh tanaman. Bekas pupuk yang menguap itu membuat daun kelihatan seperti terbakar dan tentunya menghambat pertumbuhan tanaman [3]. Selain itu, dosis pemberian pupuk cair secara manual menyebabkan penyemprotan tidak terukur dan tidak merata keseluruh tanaman. Pernyemprotan yang tidak terukur dan tidak merata menyebabkan pertumbuhan tanaman serta pembentukan buah tidak maksimal. Sedangkan menurut Gusnidar [4] pemberian pupuk yang tepat dosis akan berpengaruh terhadap meningkatnya produksi tanaman. Respon tanaman terhadap pemberian pupuk akan meningkat apabila pupuk yang digunakan tepat jenis, dosis, waktu dan cara pemberian. Tidak adanya pemberitahuan ketika tanah dalam kondisi kering/kelembapan rendah menyebabkan petani telat melakukan pengairan, sehingga tanaman mudah kering dan mati karena tidak adanya sistem kontrol kelembapan tanah.

Penelitian ini dirancang untuk menyelesaikan permasalahan yang dialami oleh Kelompok Tani Sumber Rejeki terletak di Dukuh Kedungjangan Desa Purwosari Kecamatan Mijen Kabupaten Semarang. Kelompok Tani Sumber Rejeki berfokus terhadap tanaman organik yang terdiri dari tanaman padi seluas 6 Hektar serta kebun buah seluas 2,4 Hektar. Pemilihan Kelompok Tani Sumber Rejeki sebagai objek penelitian dikarenakan kelompok tani ini diakui sebagai duta kelompok tani budidaya tanaman organik yang ada di daerah Semarang dan sekitarnya [5]. Keberhasilan kelompok Tani Sumber Rejeki bisa menjadi pilot project untuk dikembangkan di daerah lain. Bapak Yunus Marzuki selaku ketua Kelompok Tani Sumber Rejeki menyampaikan permasalahan yang kini dihadapi oleh petani diantaranya mengenai proses pemupukan. Permasalahan tersebut mengakibatkan tanaman kurang insentif dalam hal pemeliharaan yang berakibat proses budidaya tanaman organik terkesan tidak berkembang dari segi sistem pertanian sehingga hasil panen kurang optimal hanya sebesar 70\% tanaman yang memenuhi standar. Menurut Patti dkk. [6] jumlah unsur hara yang dibutuhkan sangat berkaitan dengan tumbuh kembang tanaman menjadi lebih baik. Jika jumlah unsur hara kurang tersedia maka pertumbuhan akan terhambat, tetapi apabila jumlah unsur hara yang tersedia lebih tinggi dari pada angka kebutuhan unsur hara, maka menyebabkan konsumsi berlebih yang juga tidak baik untuk tanaman organik. Suatu tumbuhan dikatakan deficient (kekurangan) unsur hara tertentu jika pertumbuhan terhambat, yakni hanya $80 \%$ dari pertumbuhan yang maksimum [7]. Oleh karena itu, pemenuhan unsur hara dibutuhkan dalam budidaya tanaman organik diantaranya menggunakan pupuk cair yang lebih cepat diserap tanaman.

Pupuk organik cair merupakan salah satu komponen penting dalam pertanian organik karena mengandung banyak unsur hara yang dibutuhkan tanaman seperti makro, mikro, hormon, dan asam amino. Selain itu didalam pupuk organik cair terdapat mikro-organisme yang akan memperbaiki kesuburan tanah sehingga dapat menunjang pertumbuhan dan perkembangan tanaman untuk mencukupi kebutuhan unsur hara melalui pupuk organik cair yang diserap melalui daun dan memanfaatkan nutrisi yang tersedia dalam tanah dengan lebih optimum [8]. Jenis pupuk organik cair sendiri sangat banyak, dibuat untuk menyelesaikan kebutuhan dan masalah yang ada di bidang pertanian serta untuk meningkatkan pertumbuhan dan perkembangan tanaman [9]. Kelompok Tani Sumber Rejeki memproduksi beberapa jenis pupuk organik cair, diantaranya 1) Pupuk Asam Amino; 2) Zero Waste Nuts (ZWN); 3) Pestisida Nabati (PESNAB). Asam amino mengandung keong yang berfungsi sebagai pelindung tanaman, imun dan penyubur tanah. Zero Waste Nuts (ZWN) digunakan untuk pertumbuhan tanaman serta Pestisida Nabati (PESNAB) digunakan untuk menjaga tanaman agar tidak diserang hama yang dapat menganggu pertumbuhan tanaman. 
Respon tanaman terhadap pemberian pupuk akan meningkat apabila pupuk yang digunakan tepat jenis, dosis, waktu dan cara pemberian [6]. Beberapa penelitian menunjukkan bahwa pemberian pupuk organik cair melalui daun memberikan pertumbuhan dan hasil tanaman yang lebih baik daripada pemberian melalui tanah. Semakin tinggi dosis pupuk yang diberikan maka kandungan unsur hara yang diterima oleh tanaman akan semakin tinggi, begitu pula dengan semakin seringnya frekuensi aplikasi pupuk daun yang dilakukan pada tanaman, maka kandungan unsur hara juga semakin tinggi. Namun, pemberian dengan dosis yang berlebihan justru akan mengakibatkan timbulnya gejala kelayuan pada tanaman [7].

Kelompok Tani Sumber Rejeki menggunakan pupuk cair campuran dari asam amino dan ZWN dengan perbandingan 1 liter ZWN ditambah $200 \mathrm{ml}$ asam amino. Campuran pupuk cair tadi ditambahkan air dengan perbandingan 1: 30. Sehingga dengan $1200 \mathrm{ml}$ pupuk cair ditambahkan air sebanyak 36 liter. Pemupukan pada kebun buah dilakukan 7 hari sekali dengan intensitas pemupukan sehari dua kali yaitu pagi sebelum matahari terbit sekitar jam 5 pagi dan jam 4 - 6 sore. Menurut Sintia dkk. [8] mengatakan bahwa kelembapan tanah yang terbaca oleh sensor $<400$ dengan prosentase 0-18\% berarti kondisi kelembaban tanah rendah (kering), 400 -500 kondisi tanah lembab dengan prosentase $18-52 \%$ dan kelembaban tanah $>600$ dengan prosentase $>75 \%$ kondisi tanah basah. Kelembaban tanah yang baik untuk budidaya tanaman organik adalah $200-600$.

Penelitian yang sudah ada selama ini diantaranya dilakukan oleh Khairunisa dkk. [10] yang membuat alat pemberi pupuk otomatis berbasis website yang hanya dapat diakses menggunakan komputer sehingga tidak fleksibel serta tidak digunakannya panel surya sehingga membutuhkan daya lisrik secara terus menerus. Windyasari dkk. [11] dalam penelitiannya membahas tentang pembuatan rancang bangun alat penyiraman dan pemupukan tanaman secara otomatis dengan sistem monitoring berbasis IoT dengan memanfaatkan RTC sebagai pengatur jadwal pemupukan, soil moisture sensor sebagai pengukur nilai kelembapan tanah dan smartphone untuk memonitoring pertumbuhan tanaman tanpa menggunakan solar panel sehingga diperlukan daya listrik terus menerus. Sinaga dan Aswardi [12] dalam penelitiannya membahas tentang pembuatan rancangan alat penyiram dan pemupukan otomatis menggunakan RTC dan soil moisture sensor berbasis arduino yang belum menerapkan sistem IoT dan solar panel.

Mesin Pemberi Pupuk Cair Otomatis Hemat Daya Berbasis IoT untuk Budidaya Tanaman Organik merupakan suatu inovasi teknologi tepat guna yang tidak memiliki kelemahan seperti penelitian yang sudah ada selama ini. Mesin ini bekerja menyiram tanaman dengan pupuk cair secara berkala dengan waktu yang sudah diatur sebelumnya menggunakan program arduino. Menggunakan sumber daya utama dari aki yang sudah terpasang pada pompa dan tambahan dari solar panel sehingga lebih hemat daya. Alat ini juga dilengkapi sensor kelembapan tanah yang diintegrasikan pada android sehingga dapat dioperasikan dari jarak jauh.

Penerapan teknologi mesin penyiram pupuk cair ini ditujukan untuk Kelompok Tani Sumber Rejeki yang memiliki potensi dalam budidaya tanaman organik. Teknologi ini dirancang dengan bentuk sederhana, praktis, sesuai dengan kebutuhan dan mudah dipahami serta dioperasikan. Dengan kerja mesin ini petani tidak perlu melakukan penyiraman pupuk cair, mesin ini akan memberi pupuk cair secara berkala dengan waktu yang sudah diatur sebelumnya serta dapat memantau kelembapan tanah, yang semuanya dapat dikontrol dan dioperasikan dari jarak jauh menggunakan android. Berdasarkan permasalahan diatas, peneliti merancang solusi tepat guna dengan membuat rancang bangun mesin pemberi pupuk cair otomatis hemat daya berbasis IoT untuk memaksimalkan hasil budidaya tanaman organik yang dilengkapi modul RTC, Soil Moisture Sensor serta berbasis Internet of Things yang merupakan teknologi mutakhir saat ini. Mesin ini juga memanfaatkan tenaga surya melalui solar panel sehingga penggunaan daya lebih hemat. Sehingga 
dengan penggunaan alat tersebut proses pemupukan bisa lebih merata, terjadwal, dan terukur yang mampu meningkatkan hasil panen.

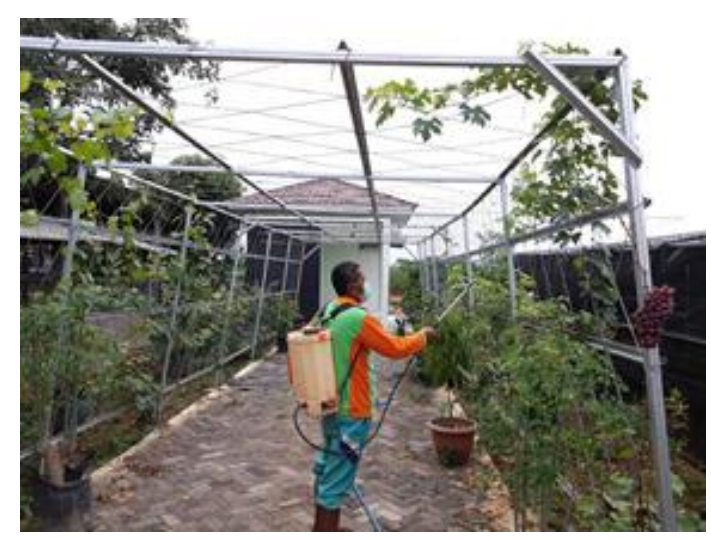

Gambar 1. Pemupukan konvensional

\section{Material dan Metodologi}

\subsection{Perencanaan Pembuatan Mesin}

Terdapat beberapa komponen yang akan digunakan berdasarkan analisa perhitungan meliputi baterai aki sebagai sumber daya utama mesin dan ketika baterai aki habis pompa masih dapat bekerja karena mendapatkan supply arus listrik dari solar panel sebagai sumber daya tambahan untuk menghemat daya. Arus listrik akan mengalir ke sistem pompa air bertenaga surya. Arduino digunakan untuk menyimpan program dari modul RTC, sensor soil moisture (Kelembapan Tanah) dan modul SIM. Modul RTC DS3231 (Real Time Clock) berfungsi untuk mengatur jadwal pemupukan, ketika sudah memasuki jadwal pemupukan, modul akan mengaktifkan relay agar katub pompa terbuka sehingga pompa menyedot pupuk cair dari tangki air yang kemudian dialirkan menuju water sprinkler melalui pipa sehingga mesin akan menyiram tanaman dengan pupuk cair secara berkala dan merata dalam waktu tertentu dengan otomatis. Sedangkan untuk mendeteksi kelembaban tanah digunakan soil moisture sensor FC-28 yang dipasang dibawah kotak panel dengan posisi tertancap kedalam tanah. Ketika kelembapan tanahnya rendah petani akan mendapat pemberitahuan dari android agar selanjutnya dilakukan pengairan sehingga kondisi tanah lebih terkontrol. Pada rangkaian ini terdapat Modul SIM yang berfungsi menghubungkan antara program Soil Moisture Sensor FC-28 dan Modul RTC dari arduino dengan android sehingga dapat menyalakan pompa tersebut kapanpun dan dimanapun dengan menggunakan android berbasis IoT.

\subsection{Perakitan}

Proses perakitan berarti penyusunan dan penyatuan beberapa bagian komponen menjadi suatu alat atau mesin yang mempunyai fungsi tertentu [13]. Perakitan dilakukan dengan membuat desain mesin pemberi pupuk cair menggunakan software Solidwork sebagai pembuatan desain 3D mesin (Gambar 3) dan dan Sketchup sebagai implementasi desain animasi mesin (Gambar 4) serta pembuatan diagram pengkawatan menggunakan software Visio (Gambar 2). Penempatan alat disesuaikan dengan luas sawah agar penyiraman pupuk cair dapat merata sesuai dengan dosisnya dalam waktu yang sudah diprogram sebelumnya. Semua data baik itu jadwal pemupukan maupun kelembapan tanah akan ditampilkan pada LCD 16x2 yang terpasang pada water sprinkler. 


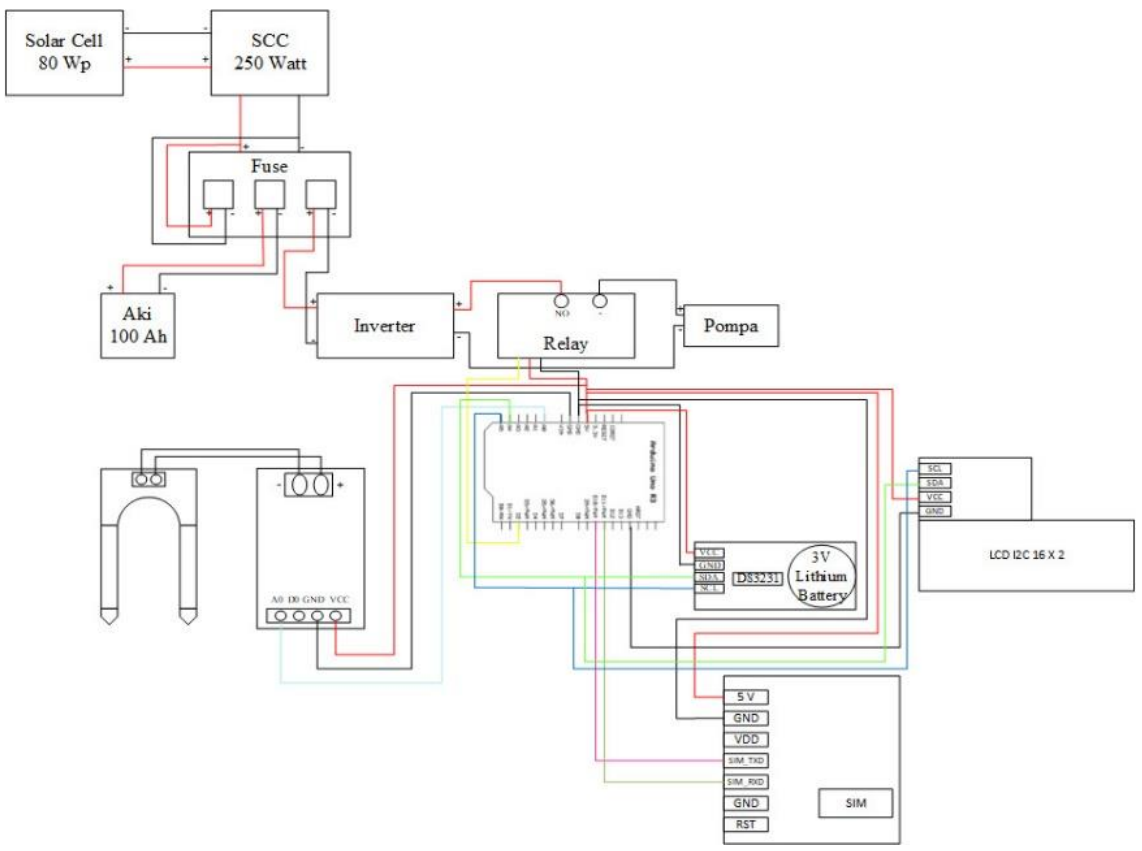

Gambar 2. Diagram pengkawatan

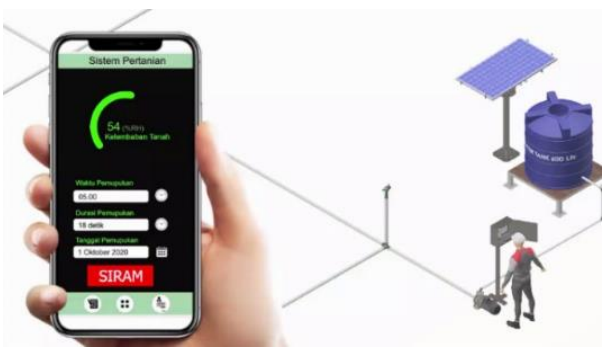

(a)

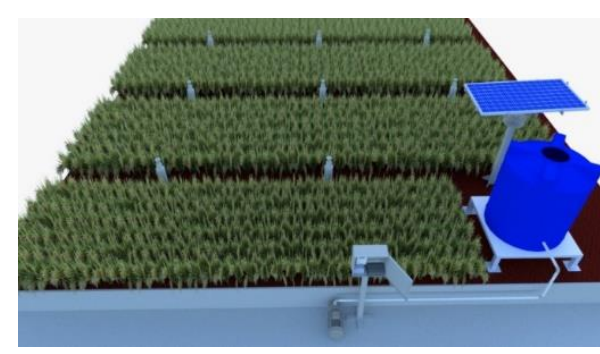

(b)

Gambar 3. (a) Desain Penerapan Mesin dan (b) Desain Penerapan Mesin pada lahan pertanian

\subsection{Penerapan Teknologi}

Penerapan teknologi yang dilakukan yaitu dengan melakukan sosialisasi mengenai cara perancangan mesin, dan simulasi pengoperasian serta perawatan mesin pemberi pupuk cair otomatis [14] kepada Kelompok Tani Sumber Rejeki dan pihak-pihak lain yang menggeluti budidaya tanaman organik.

\section{Hasil dan Pembahasan}

\subsection{Analisis Kebutuhan}

Mitra masih menggunakan metode konvensional dalam pemberian pupuk cair pada tanaman organik sehingga metode tersebut kurang efektif dan memiliki beberapa kelemahan diantaranya dosis pemberian pupuk yang tidak terukur, penyemprotan tidak merata serta waktu pemupukan yang tidak terjadwal dan terkontrol sehingga berakibat hasil panen hanya mencapai 70\%. Beberapa tuntutan yang harus diselesaikan diantaranya: penyemprotan pupuk cair yang efektif dan merata pada tanaman, penyemprotan pupuk yang terjadwal, meningkatkan hasil panen, mengurangi cycle time penyemprotan pupuk cair pada tanaman [15].

\subsection{Analisis Perhitungan}

Mesin ini memudahkan pekerjaan manusia khususnya mitra untuk melakukan pemberian pupuk karena mesin ini dapat bekerja otomatis dengan kendali android dan sangat memudahkan pekerjaan manusia karena berbasis kendali 
otomatis, juga hemat daya karena menggunakan solar cell sebagai sumber tenaga mesin selain baterai. Mesin ini juga meningkatkan proses penyemprotan pupuk cair, cycle time, dan hasil panen seperti penjelasan berikut:

1. Dosis pupuk cair

Dosis pupuk cair yang digunakan untuk sekali pemupukan adalah sebanyak $250 \mathrm{~mL}$ ditambah air sampai volume mencapai 15L untuk pemupukan lahan padi seluas $500 \mathrm{~m}^{2}$. Pemupukan lahan seluas 1 hektar (10.000 $\mathrm{m}^{2}$ ) membutuhkan 5 liter pupuk cair dan 295 liter air sebagai campuran. Sehingga tiap hektar tanah jika pemupukan dilakukan dua kali yaitu pagi dan sore dibutuhkan volume campuran pupuk cair sebanyak $600 \mathrm{~L}$.

2. Jumlah water sprinkler (WS)

Water springkler yang digunakan berspesifikasi noozle pressure $=100-150 \mathrm{kPa}$, yang mampu menjangkau seluas $50 \mathrm{~m}^{2}$ lingkaran. Untuk 1 hektar tanah dibutuhkan 200 water springkler dengan kapasitas 60.000 L/Jam. Tata letak Water Springkler berdiameter masing-masing 14 meter.

3. Kebutuhan komponen

Berikut merupakan tabel kebutuhan komponen beserta ukurannya

Tabel 1. Kebutuhan Komponen beserta ukurannya

\begin{tabular}{ll}
\hline Kebutuhan Komponen & Ukuran \\
\hline Pipa PVC 1/2 inch & $2776 \mathrm{~m}$ \\
Tangki air & $1000 \mathrm{~L}$ \\
Pompa & $60 \mathrm{~m}^{3} / \mathrm{jam}$ tipe daya $3 \mathrm{kWh}$ \\
Arus & $250 \mathrm{~A}$ \\
Baterai aki kering & $250 \mathrm{~A} / 100 \mathrm{Ah}$ \\
inverter & $12 \mathrm{VDC} / 220 \mathrm{VAC} / 3000 \mathrm{Watt}$ \\
Modul solar cell & $80 \mathrm{Wp}$ diatas $12 \mathrm{VDC}$ dimensi $1025 \times 680 \times 35 \mathrm{~mm}$ \\
Charger controller & $250 \mathrm{Wp}$ \\
\hline
\end{tabular}

\subsection{Evaluasi Hasil Mesin}

Pada evaluasi dilakukan sebuah penentuan apakah alat ini dapat mencapai dalam keberhasilan program. Jika belum tercapai akan melakukan sebuah evaluasi dengan cara melakukan pendataan apa saja yang membuat program ini belum tercapai dan melakukan riset lanjutan. Setelah dilakukan simulasi pengujian alat menghasilkan keluaran debit air $600 \mathrm{~L} /$ hektar dengan jangkauan keluaran pupuk cair yang disemprotkan $50 \mathrm{~m}^{2}$ tiap water springkler membentuk lingkaran.

Tabel 2. Perbandingan alat pemberi pupuk cair konvensional dengan mesin pemberi pupuk cair otomatis

\begin{tabular}{clll}
\hline No & Aspek & Konvensional & Mesin Siram Otomatis \\
\hline 1 & Kualitas tanaman & Panen $70 \%$ & Panen 90\% \\
2 & Sumber tenaga & Manual & Baterai dan Solar Cell \\
3 & Efisiensi Penyemprotan & Cenderung tidak merata & Merata \\
4 & Siklus Penyemprotan & Tidak terjadwal & Terjadwal \\
5 & Dosis Pupuk & Tidak teratur & Lebih Teratur \\
6 & Waktu Penyemprotan & 15 menit & 18 detik \\
\hline
\end{tabular}

Dengan mesin penyemprot pupuk cair ini, yang semula hasil panen berkisar $70 \%$ berpeluang meningkat $90 \%$. Mesin ini juga mempercepat cycle time penyemprotan pupuk cair dari 10-15 menit menjadi 15 detik. Hasil ini sesuai dengan penelitian Marpaung dkk. [2] dan Sinaga dkk. [10] yang menyatakan bahwa dengan perbaikan teknologi penyemprotan mampu meningkatkan hasil panen yang lebih baik. 
Diana Shofa dkk /Jurnal Rekayasa Mesin

p-ISSN: 1411-6863, e-ISSN: 2540-7678

Vol.16|No.1|109-115|April|2021

\section{Kesimpulan}

Penerapan teknologi penyemprotan pupuk cair agar lebih merata, terjadwal, dan terukur berpeluang meningkatkan hasil panen budidaya tanaman organik. Mesin pemberi pupuk cair otomatis berbasis IoT menjadi salah satu alternatif dalam penyelesaian masalah tersebut. Setelah dilakukan simulasi pengujian alat menghasilkan keluaran debit air 600 L/hektar dengan jangkauan keluaran pupuk cair yang disemprotkan $50 \mathrm{~m}^{2}$ tiap water springkler membentuk lingkaran. Dengan mesin penyemprot pupuk cair ini mampu mempercepat cycle time penyemprotan pupuk cair dari 10-15 menit menjadi 15 detik, jadwal pemupukan yang terkontrol dan merata berpeluang meningkatkan hasil panen yang semula berkisar $70 \%$ meningkat menjadi $90 \%$. Waktu penyemprotan yang lebih singkat, jangkauan yang lebih luas, kemudahan mengontrol alat, dan hemat daya menjadikan alat ini menarik untuk diterapkan dalam budidaya tanaman organik agar mampu menghasilkan panen yang lebih baik.

\section{Ucapan terima kasih}

Terima Kasih kami sampaikan kepada Kementrian Riset Teknologi dan Pendidikan Tinggi (Kemenristekdikti) Republik Indonesia yang telah memerikan dana hibah PKM tahun anggaran 2019-2020.

\section{Daftar Pustaka}

[1] Irsyad YMM, Kastono D. Pengaruh Macam Pupuk Organik Cair dan Dosis Pupuk Anorganik terhadap Pertumbuhan dan Hasil Jagung (Zea mays. L.). Vegetalika. 2019;8(4):263.

[2] Marpaung A, Karo B, Tarigan R. Pemanfaatan Pupuk Organik Cair dan Teknik Penanaman Dalam Peningkatan Pertumbuhan dan Hasil Kentang. J Holtikultura. 2014;24(1):49-55.

[3] Raksun A. Aplikasi Pupukorganik Untuk Meningkatkan Pertumbuhan Bibit Jambu Mete (Anacardium occidentale L.). J Biol Trop. 2016;16(2):1-9.

[4] Gusnidar. Pemanfaatan Titonia Sebagai Pupuk Alternatif dan Bahan Subtitusi Pupuk N, P, dan K, Bagi Padi Sawah Intensifikasi yang Diberi P Secara Starter. J Solum. 2017;14(2):76-82.

[5] Dispertan KBP. Pembinaan Kelompok Tani Sumber Rejeki [Internet]. 2020. Available from: https://dispertan.semarangkota.go.id

[6] Patti P., Kaya E, Silahooy C. Analisis Status Nitrogen Tanah dalam Kaitannya Dengan Serapan N Oleh Tanaman Padi Sawah di Desa Waimital, Kecamatan Kairatu, Kabupaten Seram Bagian Barat. Agrologia. 2013;2(1).

[7] Pangaribuan DH, Ginting YC, Saputra LP, Fitri H. Aplikasi Pupuk Organik Cair dan Pupuk Anorganik terhadap Pertumbuhan, Produksi, dan Kualitas Pascapanen Jagung Manis (Zea mays var. saccharata Sturt.). J Hortik Indones. 2017;8(1):59.

[8] Sintia W, Hamdani D, Risdianto E. Rancang Bangun Sistem Monitoring Kelembaban Tanah dan Suhu Udara Berbasis GSM SIM900A dan Arduino Uno. J Kumparan Fis. 2018;1(2):60-5.

[9] Febrianna M, Prijono S, Kusumarini N. Pemanfaatan Pupuk Organik Cair untuk Meningkatkan Serapan Nitrogen Serta Pertumbuhan dan Produksi Sawi ( Brassica juncea L .) Pada Tanah Berpasir. Tanah Dan Sumberd Lahan. 2018;5(2):1009-18

[10] Khairunisa C, Triyanto D, Nirmala I. Implementasi Sistem Pengendalian Pemupukan dan Penyiraman Tanaman Otomatis Berbasis Arduino Mega 2560 Dengan Antarmuka Website. J Coding, Rekayasa Sist Komput. 2018;06(03):87-96.

[11] Windyasari VS, Bagindo PA. Rancang Bangun Alat Penyiraman dan Pemupukan Tanaman Secara Otomatis Dengan Sistem Monitoring Berbasis Internet Of Things. In: Seminar Nasional Sains, Teknologi, dan Sosial Humaniora UIT 2019. 2019.

[12] Sinaga A, Aswardi. Rancangan Alat Penyiram dan Pemupukan Tanaman Otomatis Menggunakan RTC dan Soil Moisture Sensor Berbasis Arduino. JTEIN J Tek Elektro Indones. 2020;1(2):150-7.

[13] KBBI. Kamus [Internet]. 2021 [cited 2021 Mar 26]. Available from: https://kbbi.kemdikbud.go.id/.

[14] Setiadi D, Abdul Muhaemin MN. Penerapan Internet Of Things (IoT) Pada Sistem Monitoring Irigasi (Smart Irigasi). Infotronik J Teknol Inf dan Elektron. 2018;3(2):95.

[15] Shofa D, Dewi DT, Satito A. Hasil Wawancara Kelompok Tani Sumber Rejeki. Semarang; 2020. 